\title{
Troublemaking carnivores: conflicts with humans in a diverse assemblage of large carnivores
}

\author{
Andrea T. Morehouse ${ }^{1}$ and Mark S. Boyce ${ }^{1}$
}

\begin{abstract}
Human-wildlife conflicts are a global conservation and management challenge. Multipredator systems present added complexity to the resolution of human-wildlife conflicts because mitigation strategies often are species-specific. Documenting the type and distribution of such conflicts is an important first step toward ensuring that subsequent management and mitigation efforts are appropriately targeted. We reviewed 16 years of records of complaints about two species of strict carnivores, wolves (Canis lupus) and cougars (Puma concolor), and two species of omnivores, grizzly bears (Ursus arctos) and black bears (Ursus americanus) in southwestern Alberta and evaluated the temporal and spatial distribution of these complaints. Conflicts were most frequently associated with bears (68.7\% of complaint records), reflecting a diversity of conflict types attributable to their omnivorous diets. Although grizzly bears killed and injured livestock, the majority of conflicts with bears were attributable to attractants (grain and dead livestock for grizzly bears, garbage for black bears). In contrast, wolf and cougar incidents were almost exclusively related to killing or injury of livestock. Complaints for both bear species have increased over the past 16 years while cougar and wolf complaints have remained relatively constant. Grizzly bear and cougar conflicts have been expanding into private lands used for agriculture. Although community driven, targeted mitigation measures have helped reduce conflicts with grizzly bears at the site level, conflicts at the broader scale have continued to increase and continued work is necessary. Long-term human-carnivore coexistence clearly is possible, facilitated by continued monitoring and local efforts to mitigate conflicts.
\end{abstract}

Key Words: black bear; carnivores; cougar; grizzly bear; human-wildlife conflict; livestock depredation; omnivory; predation; wolf

\section{INTRODUCTION}

For many people, carnivores have intrinsic value (Leopold 1943, Kellert 1980, Bruskotter et al. 2015, Vucetich et al. 2015), and often are used as flagship species for conservation efforts (Carroll et al. 2001, Dickman et al. 2011). However, large carnivores also pose many real and perceived threats to people and communities that live within carnivore home ranges. Carnivores can kill livestock and pets (e.g., Naughton-Treves et al. 2003, Morehouse and Boyce 2011, Miller et al. 2015), cause property damage (e.g., Wilson et al. 2006, Treves 2009), affect cattle weight gain (Ramler et al. 2014), and pose a risk to human safety (e.g., Treves and Naughton-Treves 1999, Ratnayeke et al. 2014). Although separating people and carnivores at small scales, e.g., exclusion from calving pastures or yard sites, often is desirable, the separation model is unrealistic at larger scales where there is not enough space for carnivores if they are restricted from humansettled lands (e.g., Woodroffe and Ginsberg 1998, Chapron et al. 2014). Instead, facilitating coexistence between people and large carnivores is essential to carnivore persistence (Carter and Linnell 2016).

The definition of human-wildlife coexistence varies among individuals and is influenced by human values, attitudes, and tolerance, but in a general sense, human-wildlife coexistence occurs when viable populations of wildlife inhabit the same landscape as humans without infringing on the safety, rights, and property of people. Wildlife and people overlap in many regions of the world, often with varying degrees of success. In western North America, national parks and wilderness areas often were designated with scenic grandeur and tourism in mind rather than ecological processes (Newmark 1985), resulting in protected landscapes that are typically limited to "rock and ice" type habitats (Joppa and Pfaff 2009). To meet their habitat and resources needs, wide-ranging large carnivores must use resources outside of protected areas (Noss et al. 1996, Hansen and Rotella 2002), potentially bringing them in contact with human land-use activities such as livestock and crop production.

Indeed, privately owned rangelands provide valuable habitats for large carnivores outside of protected landscapes (Northrup et al. 2012, Sayre et al. 2012, Jenkins et al. 2015). Alberta provides an example of carnivores inhabiting human-settled lands, and conflicts between people and carnivores are prominent in the southwestern corner of the province (Morehouse and Boyce 2011, Alberta Government 2014a). In this region, human-settled lands used predominantly for agriculture (Statistics Canada 2011, Alberta Agriculture and Rural Development 2014) overlap with the geographical ranges of all native large carnivores including wolves (Canis lupus), cougars (Puma concolor), black bears (Ursus americanus), and grizzly bears (U. arctos). Wolf predation of livestock dominates payments made through the provincial compensation program (Morehouse and Boyce 2011; Alberta Conservation Association, unpublished data), but it is unclear if these compensation payments are reflective of the broader issue of large carnivore conflicts.

Because of their ecological importance coupled with their threats to human communities, facilitating coexistence between humans and large carnivores in shared landscapes is a pressing challenge to conservation efforts and those tasked with managing such conflicts (Decker and Chase 1997, Ripple et al. 2014). Mitigating conflicts to promote coexistence depends on accurate documentation regarding the type and distribution of conflicts over time as well as an evaluation of the biological drivers of those conflicts. 
The species responsible for damages can vary from one region to another. For example, in some regions of Africa livestock losses are due primarily to baboons (Butler 2000), whereas in other areas hyenas are the species responsible for the majority of livestock predation (Holmern et al. 2007). Thus, regional analyses are necessary to determine which species are causing the most damage and subsequently develop species-specific mitigation options. We reviewed 16 years of large-carnivore complaint records in a multipredator system and examined their spatial distribution and annual temporal patterns. Because of variation in foraging strategies (omnivory vs. carnivory), we predicted that conflicts for the bears would be more varied than for wolves and cougars that are strictly carnivorous. We discuss species-specific reasons for the observed conflict patterns, potential mitigation options to reduce conflict, and human factors influencing reporting rates. Our data represent a unique long-term study that provides insights into the global conservation challenge of human-wildlife coexistence.

\section{STUDY AREA}

We studied large carnivore conflicts in a $23,700 \mathrm{~km}^{2}$ area of southwestern Alberta (Fig. 1) that was bounded by the Highwood River to the north, British Columbia to the west, and Montana to the south. The eastern boundary was defined by the eastern extent of Wildlife Management Units in the area. Highway 3 bisected the study area; this 2-lane highway is the major east-west transportation corridor in the region. A sharp transition from agricultural land and prairie habitats to the east to mountainous forested areas to the west characterizes the region. The landscape is shaped by strong winds; cold winters follow warm, dry summers. The study area was a mix of public land $(20 \%)$ including Waterton Lakes National Park and provincial Crown lands. The remaining $80 \%$ of land within our study area was privately owned. The largest towns within the area were Pincher Creek (population 3685), Cardston (population 3580), and the Municipality of Crowsnest Pass (population 5565; Statistics Canada 2011).

Fig. 1. Map of study area in southwestern Alberta. The Municipality of Crowsnest Pass is a linear series of small towns along the Highway 3 transportation corridor.

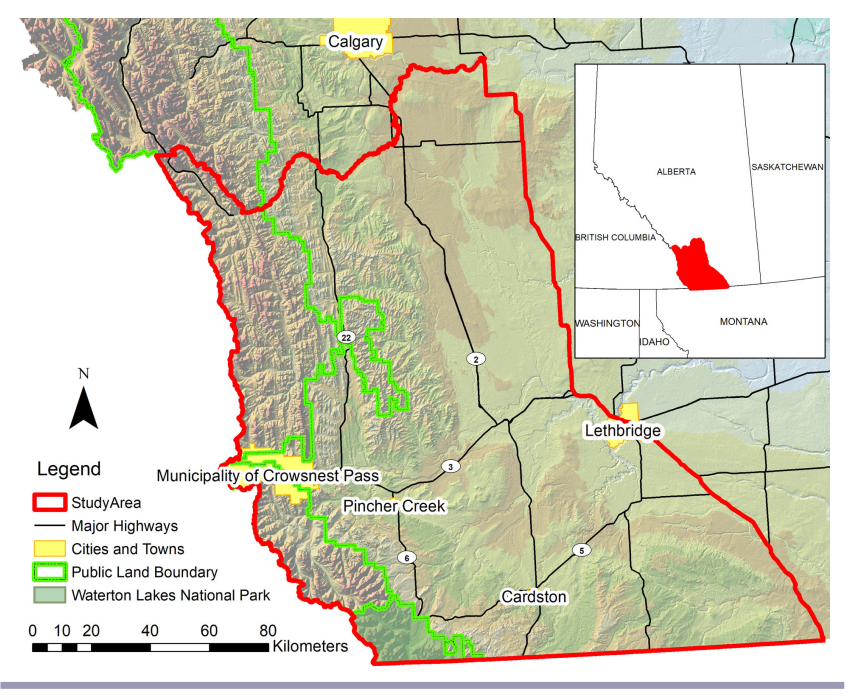

Black bear, grizzly bear, cougar, and wolf are present. With the exception of grizzly bears, all large carnivore species are considered "secure" within the province and have a hunting season (Table 1). Registration is compulsory for harvested wolves and cougars, but not for black bears (Alberta Government 2014b). Ungulates include mule deer (Odocoileus hemionus), white-tailed deer (O. virginianus), elk (Cervus canadensis), bighorn sheep (Ovis canadensis), and moose (Alces alces). Domestic cattle (Bos taurus), and a small number of sheep (Ovis aries) and goats (Capra hircus) also are present. Cattle are grazed seasonally from June through October on public forest reserve grazing allotments. Agriculture is the predominant land use on private lands (Statistics Canada 2011, Alberta Agriculture and Rural Development 2014).

Table 1. Provincial status and hunting information for each large carnivore species in southwestern Alberta. Information current as of May, 2015 (Alberta Government 2014).

\begin{tabular}{|c|c|c|c|}
\hline Species & $\begin{array}{l}\text { Provincial } \\
\text { Status }\end{array}$ & $\begin{array}{l}\text { Hunting } \\
\text { Season }\end{array}$ & $\begin{array}{l}\text { Hunting for Control of } \\
\text { Livestock Predation }^{\S}\end{array}$ \\
\hline $\begin{array}{l}\text { Grizzly Bear } \\
\text { (Ursus arctos) }\end{array}$ & Threatened & $\mathrm{no}^{\dagger}$ & no \\
\hline $\begin{array}{l}\text { Black Bear } \\
\text { (Ursus americanus) }\end{array}$ & Secure & yes & yes ${ }^{\prime}$ \\
\hline $\begin{array}{l}\text { Wolf } \\
\text { (Canis lupus) }\end{array}$ & Secure & yes $^{*}$ & yes ${ }^{\pi}$ \\
\hline $\begin{array}{l}\text { Cougar } \\
\text { (Puma concolor) }\end{array}$ & Secure & yes & yes ${ }^{\prime}$ \\
\hline \multicolumn{4}{|c|}{$\begin{array}{l}{ }^{\dagger} \text { Hunting season for grizzly bears was suspended in } 2006 \text {. } \\
\text { } \text { There is also a trapping season for wolves. } \\
{ }^{\S} \text { Heading under Alberta Hunting regulations, but there is no stipulation } \\
\text { that evidence of livestock predation must be provided. } \\
\text { 'Any owner or occupant of private land, anyone authorized to keep } \\
\text { livestock on public land, or any resident authorized by the preceding } \\
\text { may hunt on described lands without a license at all times of the year. } \\
{ }^{\uparrow} \text { Any owner or occupant of private land, anyone authorized to keep } \\
\text { livestock on public land, or any resident authorized by the preceding } \\
\text { may hunt on described lands, or any lands within } 8 \mathrm{~km} \text {, without a } \\
\text { license at all times of the year. }\end{array}$} \\
\hline
\end{tabular}

\section{METHODS}

We reviewed and categorized Government of Alberta enforcement occurrence records for grizzly bears, black bears, wolves, and cougars from the Blairmore, Cardston, Claresholm, and Pincher Creek Fish and Wildlife Districts from 1999 (date of creation of electronic occurrence database) through 2014. These occurrence records represent complaint data. When someone in Alberta makes a complaint to their local Fish and Wildlife office about large carnivores, the details of the complaint are recorded as text summaries in the provincial enforcement database. Thus, it was necessary to individually review each record to extract the pertinent information. We retained only those records reporting an actual interaction with a large carnivore; all noncarnivore records were excluded from the final database. We used the following terms (Hopkins et al. 2010) to classify each carnivore occurrence:

- Sighting: seemingly unaware of the person, no observable stress-related response during the interaction; 
- Incident: property damage, obtained anthropogenic food, killed or attempted to kill livestock or pets, or involved in a vehicle collision;

- Human conflict: physical contact with person, charged (bears) a person, or was intentionally harmed or killed by the person.

Human conflict records can include both legal and illegal harvest of carnivores. Legal harvest can include hunter harvest; we retained these records in our analysis because the occurrence records do not always provide enough detail to determine if the harvest was a result of a preceding large carnivore conflict. For example, a landowner experiencing livestock depredation may provide access to a wolf hunter who subsequently harvests several wolves from his/her property. This event might simply be reported as "legal hunter harvest" in the occurrence records. In Alberta, reporting harvested animals is only compulsory for wolves and cougars (Alberta Government 2014b).

Although we report sightings, we focus our analysis and discussion on incidents and human conflicts rather than sightings because they represent actual interactions between people and carnivores. We subdivided categories to provide more insight regarding potential driving factors. Incident type was identified as property damage, livestock, attractant, and other (primarily vehicle collisions) based on the details provided in the occurrence record; specific attractants were identified as grain, dead stock and boneyard, bee yard, silage, vegetation, garbage, bird feed, campsite, pet food, and other, e.g., horse pellets, pig feed, or wildlife hide. We excluded records that did not fit into the above categories. For example, enforcement records occasionally contained requests for information, e.g., request for bear safety information or officer presentation, or situations where a large carnivore was not actually involved, e.g., coyote mistaken for wolf. We removed these records from our database. Additionally, we excluded any records that were outside our study area.

When geographic coordinates were provided, we mapped complaint locations in a GIS (ArcMap 10.2, ESRI, Redlands, CA). Some records provided only a legal land description, i.e., quarter section, or address. In these cases, we derived GPS coordinates using the physical address or by calculating the center of the quarter section. Thus, mapped locations are accurate to the quarter section scale $(800 \times 800 \mathrm{~m})$. If we could not identify a location to the quarter-section (65 ha), we excluded the event from our maps. However, we retained all records for our summary statistics.

We summarized occurrence frequency by species and year. For incidents, we described incident type for each species and used a chi-square test to compare frequency of incident type among species. We summarized attractant type for grizzly bears and black bears and compared frequency of attractant type across the bear species using a chi-square test. To evaluate the change in distribution patterns, we calculated the distance of each occurrence from the edge of public land (to evaluate eastward progression), compared means using a single-factor ANOVA, and plotted mean distances over time.

\section{RESULTS}

We analyzed 6365 records that had accumulated over the 16-year period ( 1855 for grizzly bears, 2531 for black bears, 859 for wolves, and 1120 for cougars). Of these, locations were provided or derived for 5853 records. Cougar incidents stayed relatively constant, as did wolf incidents except for a high point in 2008 and 2009 (Fig. 2, A and B). Black bear incidents fluctuated over time and reached their highest level in 2014 (Fig. 2C). Grizzly bear incidents showed an increase beginning in 2006 (Fig. 2D).

Fig. 2. Wolf, Canis lupus (A), cougar, Puma concolor (B), black bear, Ursus americanus (C), and grizzly bear, Ursus arctos (D) occurrences by type from 1999 through 2014 in southwestern Alberta, Canada.
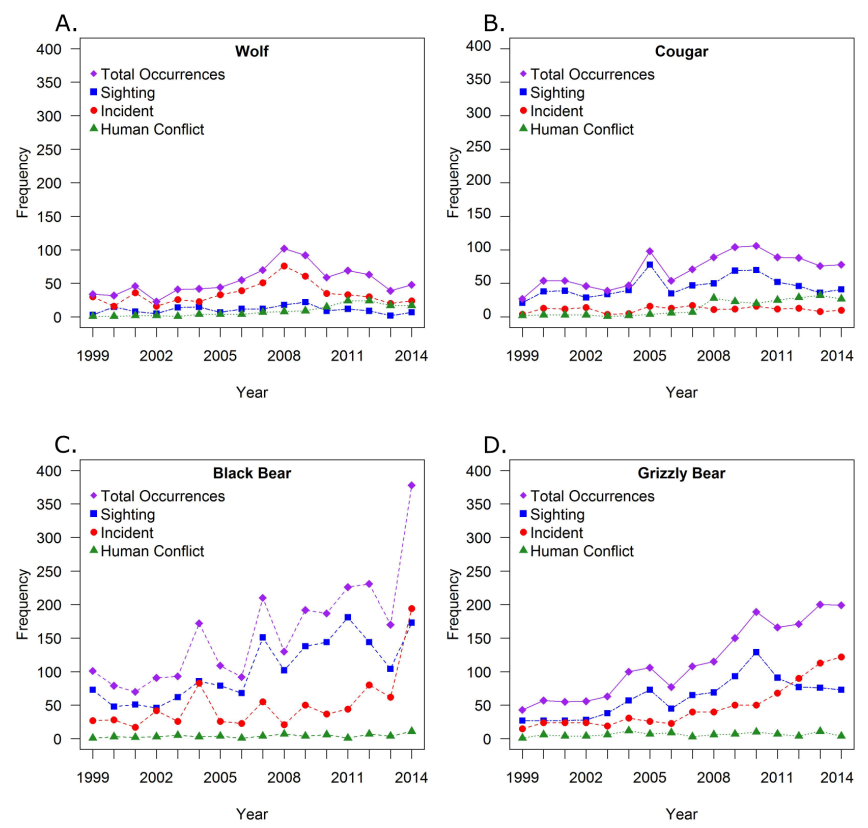

Incident type varied among species $\left(\chi_{9}^{2}=1188.9, P<0.001\right)$ and was predominantly livestock for wolves $(97.1 \%)$ and cougars (84.4\%; Fig. 3). For black bears, attractant was the most common incident type $(80.4 \%)$ (Fig. 3). Frequency of attractant type differed between bear species $\left(\chi^{2}{ }_{9}=544.8, P<0.001\right)$. The most common attractants for black bears were garbage $(37.5 \%)$, vegetation $(19.4 \%)$, and birdfeeders $(11.1 \%$; Fig. $4 \mathrm{~A})$, whereas most grizzly bear incidents were related to attractants $(55.3 \%)$ followed by livestock (39.5\%; Fig. 3). For grizzly bears, the main attractant was grain $(43.1 \%)$ followed by boneyards/deadstock (37.1\%; Fig. 4B).

The mean distance from public land of grizzly bear, black bear, and cougar occurrence records differed significantly among years (grizzly bear: $\mathrm{F}=5.1, \mathrm{df}=15, P<0.001$; black bear: $\mathrm{F}=3.8, \mathrm{df}$ $=15, P<0.001$; cougar: $\mathrm{F}=2.1$, df $=15, P=0.009)$. Mean distances from public land for grizzly bear and cougar occurrences records have increased from 1999-2014 with increasing occurrences in eastern sections of the study area (Fig. 5B and D, Fig. 6). Black bear occurrence records had a slight negative trend and average distance from public land has decreased (Fig. 5C). Wolf mean distance to public land did not differ significantly across years $(\mathrm{F}=1.2$, df $=15, P=0.231$; Fig. 5A $)$. 
Fig. 3. Large carnivore incidents by species and type (grizzly bear, Ursus arctos; black bear, Ursus americanus; wolf, Canis lupus; and cougar, Puma concolor). Percentages are cumulative over 1999 through 2014.

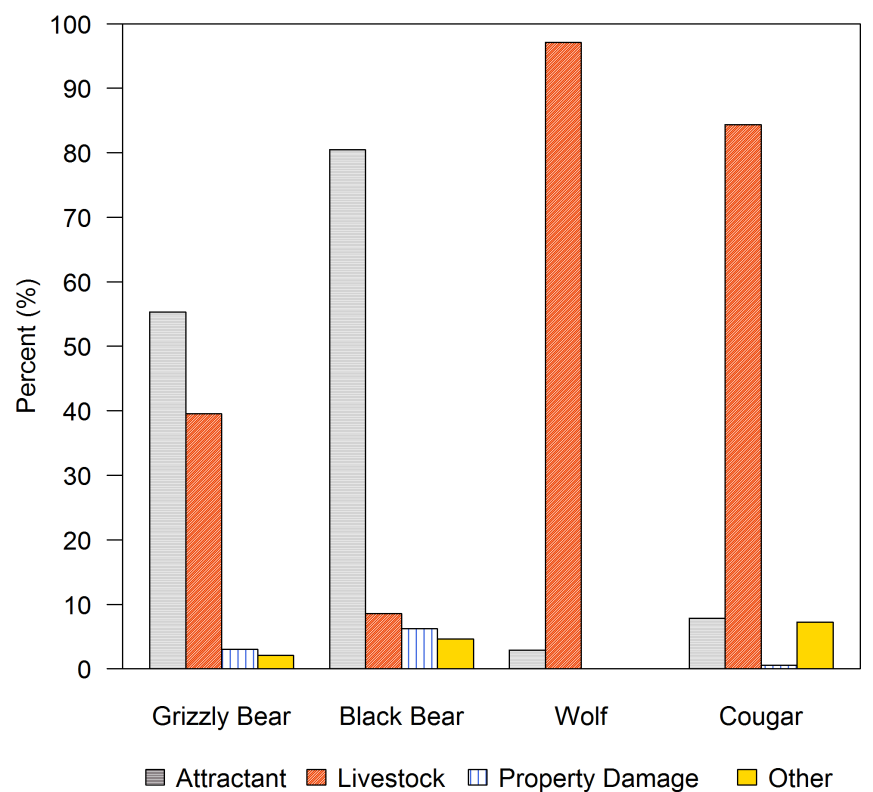

Fig. 4. Primary attractants for (A) black bear, Ursus americanus $(n=816)$ and $(B)$ grizzly bear, Ursus arctos incidents $(n=420)$ in occurrence records in southwestern Alberta, Canada 19992014.

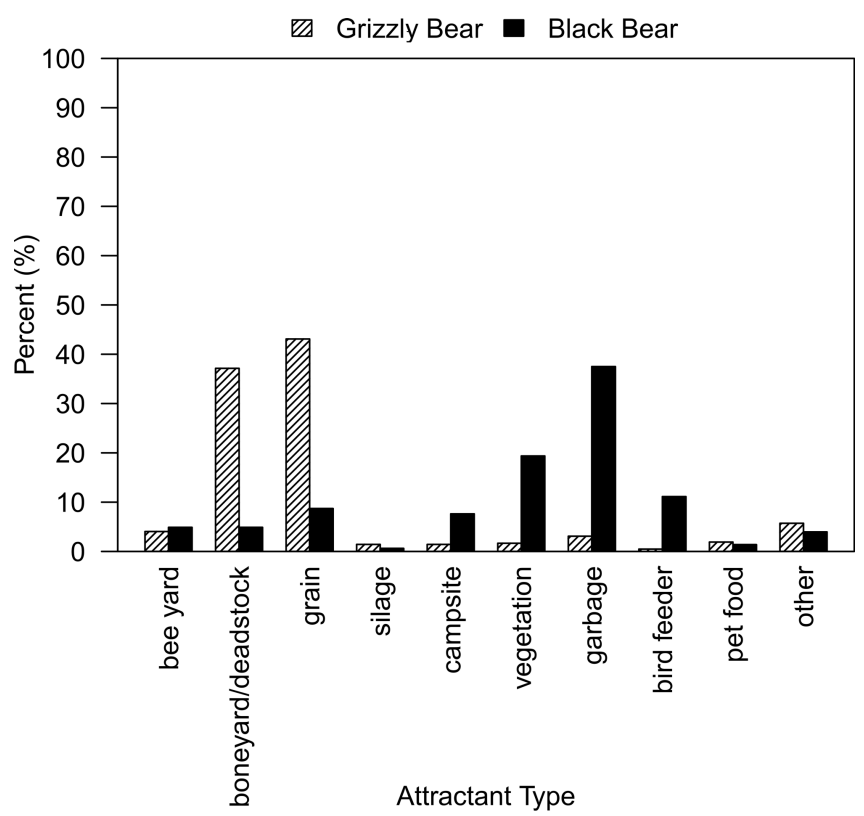

Fig. 5. Average distance in meters of occurrence records from the public land boundary by species and year (wolf, Canis lupus; cougar, Puma concolor; black bear, Ursus americanus; and grizzly bear, Ursus arctos). Data are from southwestern Alberta, Canada.
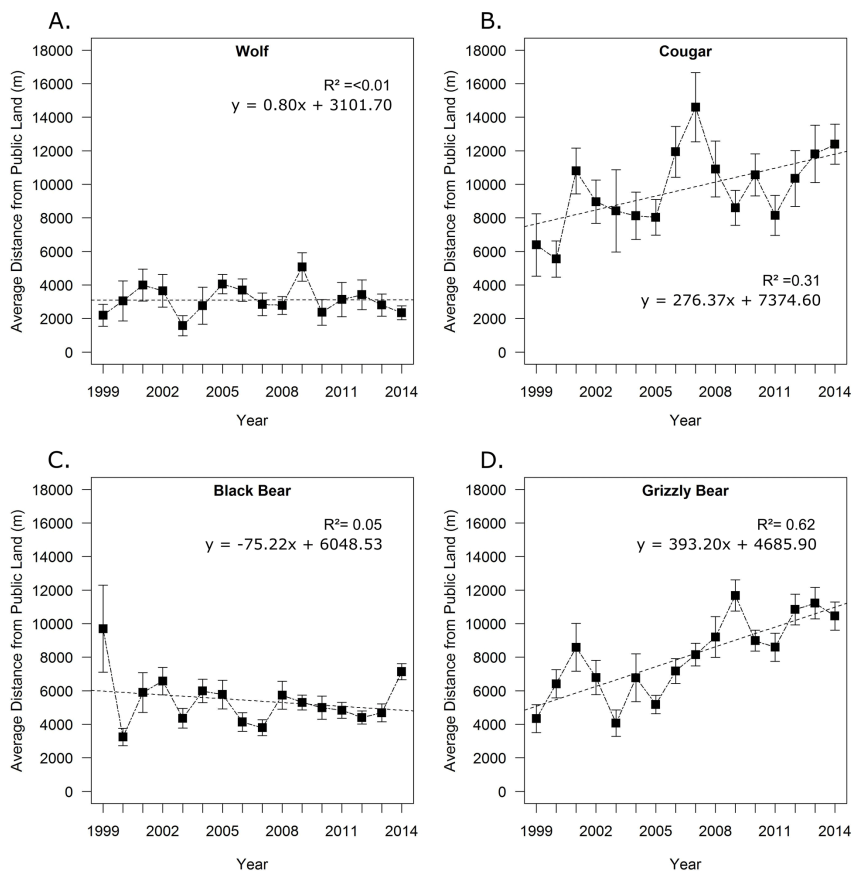

Fig. 6. Spatial locations of grizzly bear (Ursus arctos) occurrences records in southwestern Alberta, Canada 1999 through 2014 grouped in four-year increments. The shaded green area represents the public land portion of the study area.
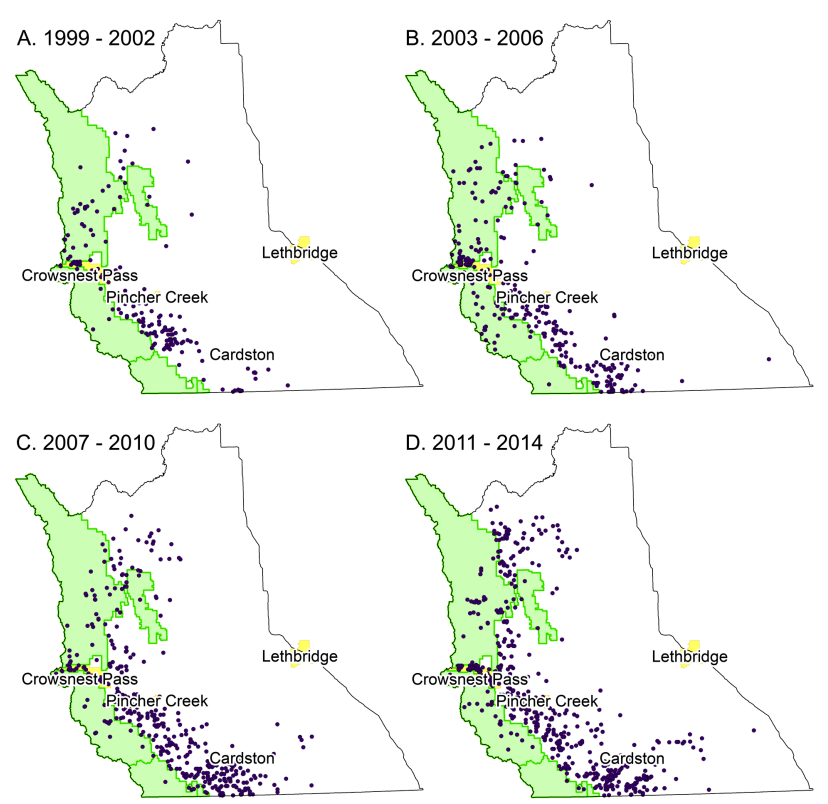
In total for all species, we classified 522 occurrences as human conflicts. Of these, 414 resulted in human-caused death of the carnivore (grizzly bear $n=28$, black bear $n=50$, wolf $n=135$, cougar $n=201$ ). The most common reasons for humans killing carnivores were legal hunter harvest $(46.4 \%)$ and defense of property $(30.4 \%)$.

\section{DISCUSSION}

Accurate documentation of human-wildlife conflict patterns helps target conflict resolution, and provides a baseline against which to measure future conflict mitigation program success. Within our study area, the human population is stable to decreasing (Statistics Canada 1996, 2001, 2006, 2011, 2016), and land tenure has remained constant at a landscape level, i.e., no change in the proportion of private land. Southwestern Alberta municipalities are characterized by remote properties with little subdivision, and are not experiencing the same urban sprawl as municipalities closer to Calgary, the major urban center of southern Alberta (Miistakis Institute for the Rockies 2003). Demographic data suggests an aging population with little mobility; the majority of the population lived at the same address five years ago for each of the three census years considered (Statistics Canada 1996, 2001, 2006, 2011, 2016), suggesting that changes in reporting rates are not driven by new residents unaccustomed to living with carnivores. Therefore, we eliminate human population increase and changes in demographics as the main reasons behind increasing carnivore conflicts, and focus instead on explanations pertinent to each species, as well as human factors that influence reporting rates.

Species-specific behaviors offer explanations for the observed patterns in the occurrence records. Similar to other multipredator systems where felids typically killed fewer livestock than other predators (e.g., Rigg et al. 2011, Karanth et al. 2012), cougar livestock incidents were the lowest of all carnivores in our study despite an expanding and increasing population (Knopff et al. 2014). Although cougars occasionally kill livestock, cougar diet in southwestern Alberta, like many regions of North America, is primarily deer (Anderson and Lindzey 2003, Knopff et al. 2009, Bacon et al. 2011, Banfield 2012). The preferred prey mass for cougars is $70-165 \mathrm{~kg}$ (Murphy and Ruth 2009), which is lower than cattle weights (predominant livestock in study area). Even in areas of high cougar and livestock density, deer are preferred prey (Bacon et al. 2011). Despite the widespread global availability of livestock, Newsome et al. (2015) found that livestock composed on average only $17 \%$ of food items in felid diets.

Similarly, wolf incidents were almost exclusively livestock related, but occurred more frequently than for cougars. The 2008 and 2009 peaks in wolf incidents coincide with our previous research in the area when we identified wolf kill sites using GPS radio collars (Morehouse and Boyce 2011). Missing livestock, i.e., animals not located at the end of the grazing season, are a concern for ranchers, and previous research indicates that these missing livestock often were depredated by wolves (Morehouse and Boyce 2011). However, without the use of GPS radio collars to locate wolf kill sites many depredated livestock are not found. Thus, data from 2008 and 2009 are likely more representative of the true number of incidents in the area rather than the outliers they appear to be. Radio telemetry can also be used as a tool to deter collared animals from livestock, thereby potentially reducing predation events (e.g., Stone et al. 2017).

Further, wolves are opportunistic, flexible hunters with diets depending on availability and vulnerability of prey (Huggard 1993, Cressman and Garay 2011, Morehouse and Boyce 2011, Metz et al. 2012), and livestock depredation by wolves is common in many areas of the world (e.g., Rigg et al. 2011, Li et al. 2015, Ali et al. 2016, Fernández-Gil et al. 2016). Wild prey have evolved various predator-avoidance strategies (Fortin et al. 2005, Laporte et al. 2010), whereas cattle lack consistent, predictable, and timely predator-avoidance strategies (Laporte et al. 2010, Muhly et al. $2010 a$ ), making them potentially more vulnerable to predation. When cattle are free ranging, however, the wolf-cattle depredation problem is particularly complex. Grazing season in North America typically coincides with the wolf pup-rearing season when the nutritional demands of wolves are considerable because of the need to satisfy growing pups, potentially heightening cattle depredation risk (Fritts et al. 2003). Full wolf pack removal can reduce future livestock depredation events in a local area (Bradley et al. 2015), but lethal control is not always socially acceptable (Bruskotter et al. 2009). Nonlethal options including increased human presence (e.g., range-riding: horseback riders monitoring livestock), livestock guardian dogs, changes in cattle age classes, electric fencing and fladry (a string of flags hung along a fence), and changing calving dates have helped reduce livestock depredation in certain situations (Shivik and Martin 2000, Smith et al. 2000, Bradley and Pletscher 2005, Shivik 2006, Muhly et al. 2010b, Breck et al. 2011, Barnes 2015). Such methods, however, often are only successful for short, e.g., 60 days, durations (Musiani et al. 2003, Shivik 2006), and wolf predation of livestock remains a challenging problem wherever wolves and livestock overlap.

Macronutrient requirements might also play a role in carnivore predation on livestock; in a laboratory setting domestic dogs selected a diet lower in protein but higher in lipids (Kohl et al. 2015), and meat from domestic livestock is typically higher in lipid content than meat from wild prey (Eaton and Konner 1985, Davidson et al. 2011, Coogan and Raubenheimer 2016). This diet preference of dogs contrasts that of domestic cats, which selected diets highest in protein energy (Hewson-Hughes et al. 2013, Kohl et al. 2015). If wolves and cougars are selecting diets that optimize their macronutrient intake, then these differences in nutrient selection between species might explain the higher proportion of livestock killed by wolves as compared to cougars, both in our study and around the world (Newsome et al. 2015).

In contrast to many of the strictly carnivorous species in the order Carnivora, bears are omnivores, resulting in more varied incident types. Because of their ability to exploit a wide range of food sources, omnivores often are associated with human-wildlife conflicts. In addition to bears, omnivorous species including wild boars (Sus scrofa), collared peccaries (Tayassu tajacu), skunks (Conepatus chinga), badgers (Meles meles), and Andean foxes (Pseudalopex culpaeus) are responsible for human-wildlife conflicts in many regions of the world (Young 1997, Rao et al. 2002, Pérez and Pacheco 2006, Delahay et al. 2009, Thapa 2010). Further, omnivores are better suited to adapt to increasingly urbanized environments (Baker and Harris 2007, Kark et al. 2007, Gilleland 2010). Nonpredation incidents are typically not reflected in predator compensation payments, highlighting the importance 
of reviewing complaint data so that mitigation can be most appropriately targeted. Jurisdictions outside Alberta maintain similar databases, and we suggest that evaluating these data can provide important insights into large carnivore conflicts.

Similar to the patterns found by our occurrence record review, crops, food waste, and livestock carcasses feature prominently in the diet of ursids across the globe; killing of livestock occurs less frequently (Newsome et al. 2015). Both black bears and grizzly bears preferentially select mixed diets (Erlenbach et al. 2014, Coogan and Raubenheimer 2016, Costello et al. 2016). For example, in a recent study in Wyoming bears consumed 1-20 different foods per day, with an average of 7.3 (Costello et al. 2016). Black bear use of human-settled areas and associated food sources often increases when natural foods are scarce (Howe et al. 2010, Baruch-Mordo et al. 2014, Lewis et al. 2014). Although not monitored, a poor berry year and decreased natural foods in 2014 could explain some of the observed 2014 increase in black bear incidents. In our study, black bear incidents were predominately attributable to attractants including garbage, birdfeeders, and vegetation. The provincial government's BearSmart program, active in the Crowsnest Pass since 2006 (http://www.bearsmart.alberta.ca), focuses on reducing attractants within local communities (e.g., removal of birdfeeders during summer, replacing fruiting trees with nonfruiting trees, etc.), securing garbage until pick-up (Solid Waste Collection and Disposal Bylaw 863, 2013), and aversive conditioning programs to discourage black bears from visiting these communities. Providing technical assistance to an individual experiencing black bear problems can be a more effective long-term solution than relocation of the problem black bear, though human behaviors take time to change (Campbell 2012, Voyles et al. 2015).

Like black bears, grizzly bears are omnivorous, but they typically occupy a wider range of habitats than do black bears, and are more likely to occur in open habitats than black bears (Herrero 1978, Apps et al. 2006). Grizzly bears are exposed not only to different attractants, but in some instances their physical strength and long claws allowed them to better access these attractants. For example, grizzly bears will dig at the base of a grain bin, ripping through a wooden floor until grain is exposed (Fig. 7). Additionally, they are the more carnivorous of the two bear species (Fortin et al. 2013) and grizzly bear depredation and/or injury of livestock was documented in the occurrence records. Grizzly bears prefer a mixed diet including $17 \%$ protein energy, with lipid and carbohydrates as nonprotein energy sources (Erlenbach et al. 2014). When natural foods high in carbohydrates and lipids such as seeds and nuts are scarce, bears might increase their use of high-carbohydrate and high-lipid anthropogenic foods such as grain (Coogan and Raubenheimer 2016).

Grizzly bear incidents increased most markedly since 2006 when Alberta suspended grizzly bear hunting (Alberta Sustainable Resource Development and Alberta Conservation Association 2010). The resulting incident increase could be due to changes in bear behavior in the absence of hunting (Swenson 1999, Ordiz et al. 2012, Penteriani et al. 2016), or an increase in reporting rates (Howe et al. 2010), which could reflect increased frustration from the community because of the loss of a sense of control, i.e., landowners can no longer remove a problem bear. Alternatively, increasing grizzly bear incidents could be due to an increased population of grizzly bears (Morehouse and Boyce 2016). Grizzly bears in southwestern Alberta are a small part of a larger, increasing international grizzly bear population that includes Montana and British Columbia (Mace et al. 2012, Proctor et al. 2012, Morehouse and Boyce 2016). Though it is important to note that an increase in bear population does not necessarily mean an increase in conflicts (Bautista et al. 2017).

Fig. 7. Examples of grain bin damage caused by grizzly bears (Ursus arctos) in our study area. Photo credits clockwise from top left are Andrea Morehouse, Nora Manners, Alberta Environment and Parks/Waterton Biosphere Reserve Association remote trail camera, Spencer Rettler.

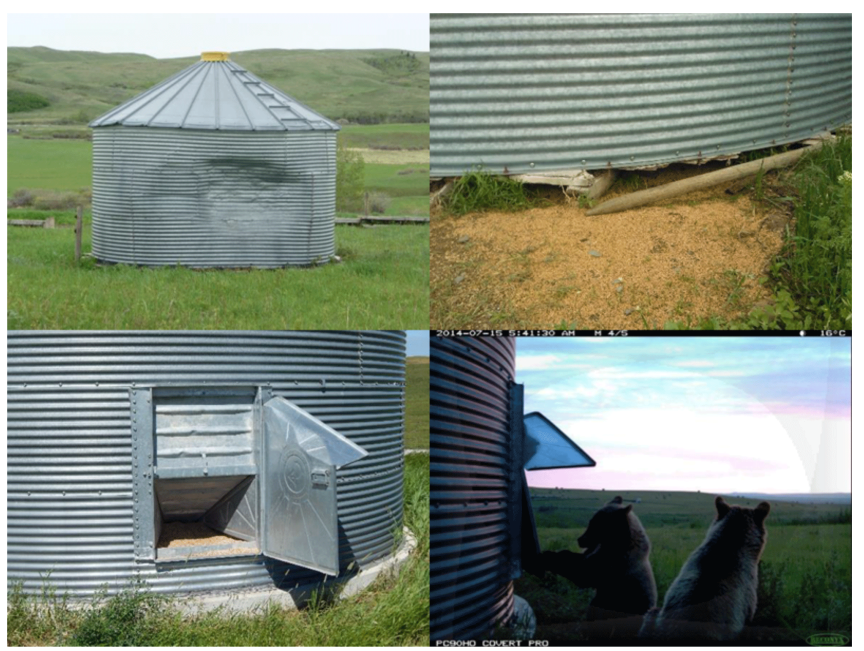

Aside from species-specific reasons, temporal trends in occurrence records might be due to changes in reporting rates (Howe et al. 2010). Complaint data are restricted to occurrences reported by the public; we cannot account for unreported carnivore occurrences. Increasing complaints might be due to a change in human attitudes and tolerance toward large carnivores. Various factors can affect attitudes including, but not limited to, personal experience with carnivores, economic circumstances, socio-demographic parameters, knowledge, and the location of the carnivore interaction (e.g., Lindsey et al. 2013, Kansky and Knight 2014, Kansky et al. 2014). Individuals encountering a carnivore for the first time, e.g. landowners living on the expanding edge of grizzly bear range, might be more inclined to report an issue than an individual who has experienced large carnivores for decades. Similarly, reporting rates might reflect an individual's frustration with regulations. In Alberta, it is within a landowner's legal right to kill a black bear, wolf, or cougar that is depredating livestock; but he/she has no such ability for grizzly bears, and must rely on the provincial government to relocate a problem bear. Individuals are 1000 times more likely to accept voluntary risks than those imposed on them externally (Starr 1969), and reporting rates might be affected if individuals blame government agencies for imposing the risks of large carnivores on them (Dickman 2010). Reporting rates could also be affected by changes on the agency side including advertising campaigns that encourage reporting, and different regional staff with better or worse public relations. 
Numerous tools are available to help mitigate conflicts, and often focus on restricting access to attractants (e.g., Table 1; Dickman 2010). Attractant management is a powerful tool for separating people and carnivores (e.g., Wilson et al. 2005, Bino et al. 2010). Globally, fencing, grain-bin retrofits, noise/light stimuli, livestock guardian dogs, aversive conditioning, and fladry have been used to restrict access/deter large carnivores (e.g., Bangs and Shivik 2001, Breck et al. 2002, Musiani et al. 2003, Wilson et al. 2005, Van Bommel and Johnson 2012). Long-term solutions to humanwildlife issues, however, must address both scientific and nonscientific considerations (Clark 2011). For example, a dead stock removal project in Montana was initially met with concern from ranchers because they did not want to disclose their calf losses out of fear they would be stigmatized as having poor animal husbandry practices (Wilson et al. 2014). Once this concern was addressed, the program enjoyed high participation and numerous carcasses, a major attractant for all large carnivores, were removed from the landscape (Wilson et al. 2014).

Similarly, in Alberta, the Waterton Biosphere Reserve's Carnivores and Communities Program engages landowners, ranchers, biologists, and managers to work together on numerous conflict-reduction projects. For example, $>50$ attractant management projects have been completed from 2008-spring 2017 in conjunction with the Waterton Biosphere Reserve's Carnivores and Communities Program (Loosen, Manners, and Morehouse 2014, Waterton Biosphere Reserve unpublished data). The diversity of nonlethal tools highlights the need for multiple mitigation options because there is no single solution to the complex problem of human-carnivore conflict. These projects require extensive time, financial resources, and often a change in ranch management; their completion is indicative of the community's commitment to reducing conflicts between carnivores and agricultural activities (Loosen, Manners, and Morehouse 2014, Waterton Biosphere Reserve unpublished data). Continued tracking of complaint records can be used to help evaluate the efficacy of mitigation efforts once implemented.

\section{CONCLUSION}

Carnivore life histories influence conflict patterns. Resolving large-carnivore human conflicts is a problem beyond the scope of biology; successful mitigation programs will integrate concepts from biology, ecology, economics, agricultural sciences, rangeland ecology, sociology, and anthropology both in program design and evaluation (Redpath et al. 2013, Kansky and Knight 2014). Mitigation options require methods that are realistic to implement and economically viable for the human communities experiencing conflicts (e.g., Huygens and Hayashi 1999, Barrett et al. 2014, Papworth et al. 2014). Current attractant management work in southwestern Alberta provides a successful example of an interdisciplinary collaboration by drawing on expertise from ranchers, biologists, and wildlife managers. These site-specific mitigation measures, together with our occurrence record review framework, can serve as an example for other regions of the world on how to evaluate carnivore conflict data, and match mitigation strategies to the species, conflicts, and human communities present. An interdisciplinary approach together with continued monitoring of complaint data is necessary to identify problem areas, improve mitigation efforts, and facilitate long-term coexistence between people and large carnivores.
Responses to this article can be read online at: http://www.ecologyandsociety.org/issues/responses. php/9415

\section{Acknowledgments:}

Funding, in-kind, and logistical support for this research was provided by Alberta Conservation Association Grants in Biodiversity, Alberta Ecotrust, Alberta Innovates - Bio Solutions, Alberta Sport Recreation Parks and Wildlife Foundation, Disney Worldwide Conservation Fund, Drywood Yarrow Conservation Partnership, Environment Canada Science Horizons, Government of Alberta, Hab-Tec Environmental, International Association for Bear Research and Management, Minister's Special License, Miistakis Institute, Nature Conservancy of Canada, Natural Sciences Engineering and Research Council of Canada, Parks Canada, Safari Club International Foundation, Safari Club International Northern Alberta Chapter, Shell Canada, TD Friends of the Environment Foundation, University of Alberta, Waterton Biosphere Reserve Association, and Yellowstone to Yukon. We thank the Alberta Government for providing access to the occurrence database for southwestern Alberta as well as spatial GIS layers for our maps. We thank the technicians M. Urmson, T. Malish, S. Rettler, and A. Loosen for their assistance in reviewing occurrence records. Finally, we thank J. Bectell and N. Manners from the Waterton Biosphere Reserve for providing information related to attractant management projects.

\section{LITERATURE CITED}

Alberta Agriculture and Rural Development. 2014. 2011 Census of agriculture for Alberta. ISBN 978-0-7732-6111-2. Alberta Agriculture and Rural Development, Edmonton, Alberta, Canada. [online] URL: http://www1.agric.gov.ab.ca/\$Department/ deptdocs.nsf/all/agdex4091/\$FILE/852-6.pdf

Alberta Government. 2014a. Grizzly bear conservation in Alberta: 2013 management activities and recovery implementation. 978-1-4601-1672-2. Alberta Government, Edmonton, Alberta, Canada.

Alberta Government. 2014b. Alberta guide to hunting regulations. ISBN: 978-927698-03-7. Alberta Government, Edmonton, Alberta, Canada.

Alberta Sustainable Resource Development and Alberta Conservation Association. 2010. Status of the grizzly bear (Ursus arctos) in Alberta: update 2010. Wildlife Status Report No. 37. Alberta Sustainable Resource Development, Edmonton, Alberta, Canada.

Ali, U., R. A. Minhas, M. S. Awan, K. B. Ahmed, Q. Z. Qamar, and N. I. Dar. 2016. Human-grey wolf (Canis lupus Linnaeus, 1758) conflict in Shounther Valley, District Neelum, Azad Jammu and Kashmir, Pakistan. Pakistan Journal of Zoology 48:861-868.

Anderson Jr, C. R., and F. G. Lindzey. 2003. Estimating cougar predation rates from GPS location clusters. Journal of Wildlife Management 67:307-316. http://dx.doi.org/10.2307/3802772

Apps, C. D., B. N. McLellan, and J. G. Woods. 2006. Landscape partitioning and spatial inferences of competition between black 
and grizzly bears. Ecography 29:561-572. http://dx.doi. org/10.1111/j.0906-7590.2006.04564.x

Bacon, M. M., G. M. Becic, M. T. Epp, and M. S. Boyce. 2011. Do GPS clusters really work? Carnivore diet from scat analysis and GPS telemetry methods. Wildlife Society Bulletin 35:409-415. http://dx.doi.org/10.1002/wsb.85

Baker, P. J., and S. Harris. 2007. Urban mammals: what does the future hold? An analysis of the factors affecting patterns of use of residential gardens in Great Britain. Mammal Review 37:297-315. http://dx.doi.org/10.1111/j.1365-2907.2007.00102.x

Banfield, J. E. 2012. Cougar response to roads and predatory behaviour in southwestern Alberta. Thesis. University of Alberta, Edmonton, Alberta, Canada.

Bangs, E., and J. Shivik. 2001. Managing wolf conflict with livestock in the Northwestern United States. Carnivore Damage Prevention News 3:2-5.

Barnes, M. 2015. Livestock management for coexistence with large carnivores, healthy land and productive ranches. People and Carnivores, Bozeman, Montana, USA. [online] URL: http:// www.peopleandcarnivores.org/PC 2015 WhitePaper.pdf

Barrett, M. A., D. J. Telesco, S. E. Barrett, K. M. Widness, and E. H. Leone. 2014. Testing bear- resistant trash cans in residential areas of Florida. Southeastern Naturalist 13:26-39. http://dx.doi. org/10.1656/058.013.0102

Baruch-Mordo, S., K. R. Wilson, D. L. Lewis, J. Broderick, J. S. Mao, and S. W. Breck. 2014. Stochasticity in natural forage production affects use of urban areas by black bears: implications to management of human-bear conflicts. PLOS ONE 9:e85122. http://dx.doi.org/10.1371/journal.pone.0085122

Bautista, C., J. Nabes, E. Revilla, N. Fernández, J. Albrecht, A. K. Scharf, R. Rigg, A. A. Karamanlidis, K. Jerina, D. Huber, et al. 2017. Patterns and correlates of claims for brown bear damage on a continental scale. Journal of Applied Ecology 54:282-292. http://dx.doi.org/10.1111/1365-2664.12708

Bino, G., A. Dolev, D. Yosha, A. Guter, R. King, D. Saltz, and S. Kark. 2010. Abrupt spatial and numerical responses of overabundant foxes to a reduction in anthropogenic resources. Journal of Applied Ecology 47:1262-1271. http://dx.doi. org/10.1111/j.1365-2664.2010.01882.x

Bradley, E. H., and D. H. Pletscher. 2005. Assessing factors related to wolf depredation of cattle in fenced pastures in Montana and Idaho. Wildlife Society Bulletin 33:1256-1265. http://dx.doi. org/10.2193/0091-7648(2005)33[1256:AFRTWD]2.0.CO;2

Bradley, E. H., H. S. Robinson, E. E. Bangs, K. Kunkel, M. D. Jimenez, J. A. Gude, and T. Grimm. 2015. Effects of wolf removal on livestock depredation recurrence and wolf recovery in Montana, Idaho, and Wyoming. Journal of Wildlife Management 79:1337-1346. http://dx.doi.org/10.1002/jwmg.948

Breck, S. W., B. M. Kluever, M. Panasci, J. Oakleaf, T. Johnson, W. Ballard, L. Howery, and D. L. Bergman. 2011. Domestic calf mortality and producer detection rates in the Mexican wolf recovery area: implications for livestock management and carnivore compensation schemes. Biological Conservation 144:930-936. http://dx.doi.org/10.1016/j.biocon.2010.12.014
Breck, S. W., R. Williamson, C. Niemeyer, and J. A. Shivik. 2002. Non-lethal radio activated guard for deterring wolf depredation in Idaho: summary and call for research. Pages 223-226 in R. M. Timm, and R. H. Schmidt, editors. Proceedings of the 20th Vertebrate Pest Conference. University of California, Davis, California, USA.

Bruskotter, J. T., M. P. Nelson, and J. A. Vucetich. 2015. Hunted predators: intrinsic value. Science 349:1294-1295. http://dx.doi. org/10.1126/science.349.6254.1294-b

Bruskotter, J. T., J. J. Vaske, and R. H. Schmidt. 2009. Social and cognitive correlates of Utah residents' acceptance of the lethal control of wolves. Human Dimensions of Wildlife 14:119-132. http://dx.doi.org/10.1080/10871200802712571

Butler, J. R. A. 2000. The economic costs of wildlife predation on livestock in Gokwe communal land, Zimbabwe. African Journal of Ecology 38:23-30. http://dx.doi.org/10.1046/j.1365-2028.2000.00209. $\underline{x}$

Campbell, J. M. 2012. The effect of education in reducing bear attractants on cottage properties: Manitoba's "Bear Smart" program. Forest Policy and Economics 19:56-65. http://dx.doi. org/10.1016/j.forpol.2012.02.013

Carroll, C., R. F. Noss, and P. C. Paquet. 2001. Carnivores as focal species for conservation planning in the Rocky Mountain region. Ecological Applications 11:961-980. http://dx.doi.org/10.1890/1051-0761 (2001)011[0961:CAFSFC]2.0.CO;2

Carter, N. H., and J. D. C. Linnell. 2016. Co-adaptation is key to coexisting with large carnivores. Trends in Ecology and Evolution 31:575-578. http://dx.doi.org/10.1016/j.tree.2016.05.006

Chapron, G., P. Kaczensky, D. J. D. C. Linnell, M. von Arx, D. Huber, H. Andrén, J. V. López- Bao, M. Adamec, F. Álvares, O. Anders, et al. 2014. Recovery of large carnivores in Europe's modern human-dominated landscapes. Science 346:1517-1519. http://dx.doi.org/10.1126/science. 1257553

Clark, S. G. 2011. The policy process: a practical guide for natural resource professionals. Yale University Press, New Haven, Connecticut, USA.

Coogan, S. C. P., and D. Raubenheimer. 2016. Might macronutrient requirements influence grizzly bear-human conflict? Insights from nutritional geometry. Ecosphere 7(1): e01204. http://dx.doi.org/10.1002/ecs2.1204

Costello, C. M., S. L. Cain, S. Pils, L. Frattaroli, M. A. Haroldson, and F. T. van Manen. 2016. Diet and macronutrient optimization in wild ursids: a comparison of grizzly bears with sympatric and allopatric black bears. PLoS ONE 11:e0153702. http://dx.doi. org/10.1371/journal.pone.0153702

Cressman, R., and J. Garay. 2011. The effects of opportunistic and intentional predators on the herding behavior of prey. Ecology 92:432-440. http://dx.doi.org/10.1890/10-0199.1

Davidson, B., J. Maciver, E. Lessard, and K. Connors. 2011. Meat lipid profiles: a comparison of meat from domesticated and wild southern African animals. In Vivo 25:197-202.

Decker, D. J., and L. C. Chase. 1997. Human dimensions of living with wildlife: a management challenge for the 21 st century. Wildlife Society Bulletin 25:788-795. 
Delahay, R. J., J. Davison, D. W. Poole, A. J. Matthews, C. J. Wilson, M. J. Heydon, and T. J. Roper. 2009. Managing conflict between humans and wildlife: trends in licensed operations to resolve problems with badgers Meles meles in England. Mammal Review 39:53-66. http://dx.doi.org/10.1111/j.1365-2907.2008.00135. $\underline{\mathrm{x}}$

Dickman, A. J. 2010. Complexities of conflict: the importance of considering social factors for effectively resolving human-wildlife conflict. Animal Conservation 13:458-466. http://dx.doi. org/10.1111/j.1469-1795.2010.00368.x

Dickman, A. J., E. A. Macdonald, and D. W. Macdonald. 2011. A review of financial instruments to pay for predator conservation and encourage human-carnivore coexistence. Proceedings of the National Academy of Sciences 108:13937-13944. http://dx.doi. org/10.1073/pnas.1012972108

Eaton, S. B., and M. Konner. 1985. Paleolithic nutrition: a consideration of its nature and current implications. New England Journal of Medicine 312:283-289. http://dx.doi.org/10.1056/ NEJM198501313120505

Erlenbach, J. A., K. D. Rode, D. Raubenheimer, and C. T. Robbins. 2014. Macronutrient optimization and energy maximization determine diets of brown bears. Journal of Mammalogy 95:160-168. http://dx.doi.org/10.1644/13-MAMMA-161

Fernández-Gil, A., J. Naves, A. Ordiz, M. Quevedo, E. Revilla, and M. Delibes. 2016. Conflict misleads large carnivore management and conservation: brown bears and wolves in Spain. PLoS ONE 11:e0151541. http://dx.doi.org/10.1371/journal. pone. 0151541

Fortin, D., H. L. Beyer, M. S. Boyce, D. W. Smith, T. Duchesne, and J. S. Mao. 2005. Wolves influence elk movements: behavior shapes a trophic cascade in Yellowstone National Park. Ecology 86:1320-1330. http://dx.doi.org/10.1890/04-0953

Fortin, J. K., C. C. Schwartz, K. A. Gunther, J. E. Teisberg, M. A. Haroldson, M. A. Evans, and C. T. Robbins. 2013. Dietary adjustability of grizzly bears and American black bears in Yellowstone National Park. Journal of Wildlife Management 77:270-281. http://dx.doi.org/10.1002/jwmg.483

Fritts, S. H., R. O. Peterson, R. D. Hayes, and L. Boitani. 2003. Wolves and humans. Pages 289-316 in L. D. Mech, and L. Boitani, editors. Wolves: behavior, ecology, and conservation. University of Chicago Press, Chicago, Illinois, USA.

Gilleland, A. H. 2010. Human-wildlife conflict across urbanization gradients: spatial, social, and ecological factors. Dissertation. University of South Florida, Tampa, Florida, USA.

Hansen, A. J., and J. J. Rotella. 2002. Biophysical factors, land use, and species viability in and around nature reserves. Conservation Biology 16:1112-1122. http://dx.doi.org/10.1046/ j.1523-1739.2002.00545.x

Herrero, S. 1978. A comparison of some features of the evolution, ecology and behavior of black and grizzly/brown bears. Carnivore 1:7-17.

Hewson-Hughes, A. K., V. L. Hewson-Hughes, A. Colyer, A. T. Miller, S. J. McGrane, S. R. Hall, R. F. Butterwick, S. J. Simpson, and D. Raubenheimer. 2013. Geometric analysis of macronutrient selection in breeds of the domestic dog, Canis lupus familiaris. Behavioural Ecology 24:293-304. http://dx.doi. org/10.1093/beheco/ars168

Holmern, T., J. Nyahongo, and E. Røskaft. 2007. Livestock loss caused by predators outside the Serengeti National Park, Tanzania. Biological Conservation 135:518-526. http://dx.doi. org/10.1016/j.biocon.2006.10.049

Hopkins III, J. B., S. Herrero, R. T. Shideler, K. A. Gunther, C. C. Schwartz, and S. T. Kalinowski. 2010. A proposed lexicon of terms and concepts for human-bear management in North America. Ursus 21:154-168. http://dx.doi.org/10.2192/URSUSD-10-00005.1

Howe, E. J., M. E. Obbard, R. Black, and L. L. Wall. 2010. Do public complaints reflect trends in human-bear conflict? Ursus 21:131-142. http://dx.doi.org/10.2192/09GR013.1

Huggard, D. J. 1993. Prey selectivity of wolves in Banff National Park. I. Prey species. Canadian Journal of Zoology 71:130-139. http://dx.doi.org/10.1139/z93-019

Huygens, O. C., and H. Hayashi. 1999. Using electric fences to reduce Asiatic black bear depredation in Nagano Prefecture, central Japan. Wildlife Society Bulletin 27:959-964.

Jenkins, C. N., K. S. Van Houtan, S. L. Pimm, and J. O. Sexton. 2015. US protected lands mismatch biodiversity priorities. Proceedings of the National Academy of Sciences 112:5081-5086. http://dx.doi.org/10.1073/pnas. 1418034112

Joppa, L. N., and A. Pfaff. 2009. High and far: biases in the location of protected areas. PLOS ONE 4:e8273. http://dx.doi. org/10.1371/journal.pone.0008273

Kansky, R., M. Kidd, and A. T. Knight. 2014. Meta-analysis of attitudes toward damage-causing mammalian wildlife. Conservation Biology 28:924-938. http://dx.doi.org/10.1111/cobi.12275

Kansky, R., and A. T. Knight. 2014. Key factors driving attitudes towards large mammals in conflict with humans. Biological Conservation 179:93-105. http://dx.doi.org/10.1016/j.biocon.2014.09.008

Karanth, K. K., A. M. Gopalaswamy, R. DeFries, and B. Ballal. 2012. Assessing patterns of human-wildlife conflicts and compensation around a central Indian protected area. PLOSONE 7:e50433. http://dx.doi.org/10.1371/journal.pone.0050433

Kark, S., A. Iwaniuk, A. Schalimtzek, and E. Banker. 2007. Living in the city: can anyone become an 'urban exploiter'? Journal of Biogeography 34:638-651. http://dx.doi.org/10.1111/ j.1365-2699.2006.01638.x

Kellert, S. R. 1980. American attitudes toward and knowledge of animals: an update. International Journal for the Study of Animal Problems 1:87-119.

Knopff, K. H., A. A. Knopff, M. B. Warren, and M. S. Boyce. 2009. Evaluating global positioning system telemetry techniques for estimating cougar predation parameters. Journal of Wildlife Management 73:586-597. http://dx.doi.org/10.2193/2008-294

Knopff, K. H., N. F. Webb, and M. S. Boyce. 2014. Cougar population status and range expansion in Alberta during 1991-2010. Wildlife Society Bulletin 38:116-121. http://dx.doi. org/10.1002/wsb.369 
Kohl, K. D., S. C. P. Coogan, and D. Raubenheimer. 2015. Do wild carnivores forage for prey or nutrients? BioEssays 37:701-709. http://dx.doi.org/10.1002/bies.201400171

Laporte, I., T. B. Muhly, J. A. Pitt, M. Alexander, and M. Musiani. 2010. Effects of wolves on elk and cattle behaviors: implications for livestock production and wolf conservation. PLOS ONE 5: e11954. http://dx.doi.org/10.1371/journal.pone.0011954

Leopold, A. 1943. Wildlife in American culture. Journal of Wildlife Management 7:1-6. http://dx.doi.org/10.2307/3795771

Lewis, D. L., S. W. Breck, K. R. Wilson, and C. T. Webb. 2014. Modeling black bear population dynamics in a humandominated stochastic environment. Ecological Modelling 294:51-58. http://dx.doi.org/10.1016/j.ecolmodel.2014.08.021

Li, C., Z. Jiang, C. Li, S. Tang, F. Li, Z. Luo, X. Ping, Z. Liu, J. Chen, H. Fang. 2015. Livestock depredations and attitudes of local pastoralists toward carnivores in the Qinghai Lake Region, China. Wildlife Biology 21:204-212. http://dx.doi.org/10.2981/ wlb.00083

Lindsey, P. A., C. P. Havemann, R. Lines, L. Palazy, A. E. Price, T. A. Retief, T. Rhebergen, and C. van der Waal. 2013. Determinants of persistence and tolerance of carnivores on Namibian ranches: implications for conservation on Southern African private lands. PLOS ONE 8:e52458. http://dx.doi. org/10.1371/journal.pone.0052458

Mace, R. D., D. W. Carney, T. Chilton-Radant, S. A. Courville, M. A. Haroldson, R. B. Harris, J. Jonkel, B. McLellan, M. Madel, T. L. Manley, et al. 2012. Grizzly bear population vital rates and trend in the Northern Continental Divide Ecosystem, Montana. Journal of Wildlife Management 76:119-128. http://dx.doi. org/10.1002/jwmg. 250

Metz, M. C., D. W. Smith, J. A. Vucetich, D. R. Stahler, and R. O. Peterson. 2012. Seasonal patterns of predation for gray wolves in the multi-prey system of Yellowstone National Park. Journal of Animal Ecology 81:553-563. http://dx.doi.org/10.1111/ j.1365-2656.2011.01945.X

Miistakis Institute for the Rockies. 2003. Spatial analysis of rural residential expansion in southwestern Alberta. Miistakis Institute for the Rockies, Calgary, Alberta, Canada.

Miller, J. R. B., Y. V. Jhala, J. Jena, and O. J. Schmitz. 2015. Landscape-scale accessibility of livestock to tigers: implications of spatial grain for modeling predation risk to mitigate humancarnivore conflict. Ecology and Evolution 5:1354-1367. http://dx. doi.org/10.1002/ece3.1440

Morehouse, A. T., and M. S. Boyce. 2011. From venison to beef: seasonal changes in wolf diet composition in a livestock grazing landscape. Frontiers in Ecology and the Environment 9:440-445. http://dx.doi.org/10.1890/100172

Morehouse A. T., and M. S. Boyce. 2016. Grizzly bears without borders: spatially explicit capture-recapture in southwestern Alberta. Journal of Wildlife Management 80:1152-1166. http://dx. doi.org/10.1002/jwmg.21104

Muhly, T. B., M. Alexander, M. S. Boyce, R. Creasey, M. Hebblewhite, D. Paton, J. A. Pitt, and M. Musiani. $2010 a$. Differential risk effects of wolves on wild versus domestic prey have consequences for conservation. Oikos 119:1243-1254. http:// dx.doi.org/10.1111/j.1600-0706.2009.18350.x

Muhly, T., C. C. Gates, C. Callaghan, and M. Musiani. $2010 b$. Livestock husbandry practices reduce wolf depredation risk in Alberta, Canada. Pages 261-286 in M. Musiani, L. Boitani, and P. C. Paquet, editors. The world of wolves: new perspectives on ecology, behaviour, and management. University of Calgary Press, Calgary, Alberta, Canada.

Murphy, K., and R. Ruth. 2009. Diet and prey selection of a perfect predator. Pages 118-137 in M. Hornocker and S. Negri, editors. Cougar: ecology and conservation. University of Chicago Press, Chicago, Illinois, USA.

Musiani, M., C. Mamo, L. Boitani, C. Callaghan, C. C. Gates, L. Mattei, E. Visalberghi, S. Breck, and G. Volpi. 2003. Wolf depredation trends and the use of fladry in western North America. Conservation Biology 17:1538-1547. http://dx.doi. org/10.1111/j.1523-1739.2003.00063.x

Naughton-Treves, L., R. Grossberg, and A. Treves. 2003. Rural citizens' attitudes toward wolf depredation and compensation. Conservation Biology 17:1500-1511. http://dx.doi.org/10.1111/ j.1523-1739.2003.00060.x

Newmark, W. D. 1985. Legal and biotic boundaries of western North American National Parks: a problem of congruence. Biological Conservation 33:197-208. http://dx.doi.org/10.1016/0006-3207 (85)90013-8

Newsome, T. M., J. A. Dellinger, C. R. Pavey, W. J. Ripple, C. R. Shores, A. J. Wirsing, and C. R. Dickman. 2015. The ecological effects of providing resource subsidies to predators. Global Ecology and Biogeography 24:1-11. http://dx.doi.org/10.1111/ geb. 12236

Northrup, J. M., G. B. Stenhouse, and M. S. Boyce. 2012. Agricultural lands as ecological traps for grizzly bears. Animal Conservation 15:369-377. http://dx.doi.org/10.1111/ j.1469-1795.2012.00525.x

Noss, R. F., H. B. Quigley, M. G. Hornocker, T. Merrill, and P. C. Paquet. 1996. Conservation biology and carnivore conservation in the Rocky Mountains. Conservation Biology 10:949-963. http://dx.doi.org/10.1046/j.1523-1739.1996.10040949. $\underline{\mathrm{x}}$

Ordiz, A., O.-G. Støen, S. Sæbø, J. Kindberg, M. Delibes, and J. E. Swenson. 2012. Do bears know they are being hunted? Biological Conservation 152:21-28. http://dx.doi.org/10.1016/j. biocon.2012.04.006

Papworth, S. K., A. Kang, M. Rao, S. T. Chin, H. Zhao, X. Zhao, and L. R. Carrasco. 2014. Bear-proof fences reduce livestock losses in the Tibetan Autonomous Region, China. Conservation Evidence 11:8-11.

Penteriani, V., M. M. Delgado, F. Pinchera, J. Naves, A. Fernández-Gil, I. Kojola, S. Härkönen, H. Norberg, J. Frank, J. M. Fedriani, et al. 2016. Human behaviour can trigger large carnivore attacks in developed countries. Scientific Reports 6:20552. http://dx.doi.org/10.1038/srep20552

Pérez, E., and L. F. Pacheco. 2006. Damage by large mammals to subsistence crops within a montane forest of Bolivia. Crop Protection 25:933-939. http://dx.doi.org/10.1016/j.cropro.2005.12.005 
Proctor, M. F., D. Paetkau, B. N. McLellan, G. B. Stenhouse, K. C. Kendall, R. D. Mace, W. F. Kasworm, C. Servheen, C. L. Lausen, M. L. Gibeau, et al. 2012. Population fragmentation and inter-ecosystem movements of grizzly bears in western Canada and the northern United States. Wildlife Monographs 180:1-46. http://dx.doi.org/10.1002/wmon.6

Ramler, J. P., M. Hebblewhite, D. Kellenberg, and C. Sime. 2014. Crying wolf? A spatial analysis of wolf locations and depredations on calf weight. American Journal of Agricultural Economics 96:631-656. http://dx.doi.org/10.1093/ajae/aat100

Rao, K. S., R. K. Maikhuri, S. Nautiyal, and K. G. Saxena. 2002. Crop damage and livestock depredation by wildlife: a case study from Nanda Devi Biosphere Reserve, India. Journal of Environmental Management 66:317-327. http://dx.doi.org/10.1016/ $\underline{\mathrm{S} 0301-4797(02) 90587-6}$

Ratnayeke, S., F. T. Van Manen, R. Pieris, and V. S. J. Pragash. 2014. Challenges of large carnivore conservation: sloth bear attacks in Sri Lanka. Human Ecology 42:467-479. http://dx.doi. org/10.1007/s10745-014-9643-y

Redpath, S. M., J. Young, A. Evely, W. M. Adams, W. J. Sutherland, A. Whitehouse, A. Amar, R. A. Lambert, J. D. C. Linnell, A. Watt, and R. J. Gutiérrez. 2013. Understanding and managing conservation conflicts. Trends in Ecology and Evolution 28:100-109. http://dx.doi.org/10.1016/j.tree.2012.08.021

Rigg, R., S. Find'o, M. Wechselberger, M. L. Gorman, C. SillerZubiri, and D. W. Macdonald. 2011. Mitigating carnivorelivestock conflict in Europe: lessons from Slovakia. Oryx 45:272-280. http://dx.doi.org/10.1017/S0030605310000074

Ripple, W. J., J. A. Estes, R. L. Beschta, C. C. Wilmers, E. G. Ritchie, M. Hebblewhite, J. Berger, B. Elmhagen, M. Letnic, M. P. Nelson, et al. 2014. Status and ecological effects of the world's largest carnivores. Science 343(6167). http://dx.doi.org/10.1126/ science. 1241484

Sayre, N. F., L. Carlisle, L. Huntsinger, G. Fisher, and A. Shattuck. 2012. The role of rangelands in diversified farming systems: innovations, obstacles, and opportunities in the USA. Ecology and Society 17(4):43. http://dx.doi.org/10.5751/es-04790-170443

Shivik, J. A. 2006. Tools for the edge: what's new for conserving carnivores. BioScience 56:253-259. http://dx.doi.org/10.1641/0006-3568 (2006)056[0253:TFTEWN]2.0.CO;2

Shivik, J. A., and D. J. Martin. 2000. Aversive and stimulus applications for managing predation. Pages 111-119 in M. C. Brittingham, J. Kays, and R. McPeake, editors. The Ninth Wildlife Damage Management Conferences Proceedings. University of Nebraska, Lincoln, Nebraska, USA.

Smith, M. E., J. D. C. Linnell, J. Odden, and J. E. Swenson. 2000. Review of methods to reduce livestock depredation: I. Guardian Animals. Acta Agriculturae Scandinavica 50:279-290. http://dx. doi.org/10.1080/090647000750069476

Starr, C. 1969. Social benefit versus technological risk. Science 165:1232-1238. http://dx.doi.org/10.1126/science.165.3899.1232

Statistics Canada. 1996. 1996 Community profiles: Pincher Creek No. 9, Municipal district. Statistics Canada, Ottawa, Ontario, Canada. [online] URL: http://www12.statcan.ca/english/census96/ $\underline{\text { data/profiles } / \text { Rp-eng.cfm?TABID }=2 \& L A N G=E \& A P A T H=3 \&-}$ DETAIL $=0 \& D I M=0 \& F L=A \& F R E E=0 \& G C=0 \& G I D=20411-$ $7 \& \mathrm{GK}=0 \& \mathrm{GRP}=1 \& \mathrm{PID}=35782 \& \mathrm{PRID}=0 \& \mathrm{PTYPE}=3 \& \mathrm{~S}=0 \&-$ SHOWALL $=0 \&$ SUB $=0 \&$ Temporal $=1996 \&$ THEME $=34 \&$ VID$=0 \& \mathrm{VNAMEE}=\& \mathrm{VNAMEF}=\& \mathrm{D} 1=0 \& \mathrm{D} 2=0 \& \mathrm{D} 3=0 \& \mathrm{D} 4=0 \&-$ D5 $=0 \& \mathrm{D} 6=0$

Statistics Canada. 2001.2001 Community profiles: Pincher Creek No. 9, Municipal district. Statistics Canada, Ottawa, Ontario, Canada. [online] URL: http://www12.statcan.gc.ca/english/ profi101/CP01/Details/Page.cfm?Lang=E\&Geo1= CSD\&Code $1=4803011 \&$ Geo $2=$ PR $\&$ Code $2=48 \&$ Data $=$ Count $\&$ SearchText $=$ Pincher $\% 20$ Creek $\&$ SearchType $=$

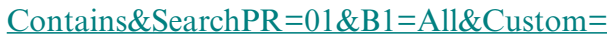

Statistics Canada. 2006. 2006 Community profiles: Pincher Creek No. 9, Municipal district. Statistics Canada, Ottawa, Ontario, Canada. [online] URL: http://www12.statcan.ca/census-recensement/2006/ dp-pd/prof/92-591/details/page.cfm?Lang=E\&Geo1= CSD $\&$ Code $1=4803011 \&$ Geo $2=$ PR $\&$ Code $2=48 \&$ Data $=$ Count $\&$ SearchText $=$ Pincher $\% 20$ Creek $\% 20$ No $\% 209 \&$ SearchType $=$ Begins $\&$ SearchPR $=01 \&$ B1 $=$ All $\&$ GeoLevel $=$ PR \&GeoCode $=4803011$

Statistics Canada. 2011. 2011 Census profiles. Statistics Canada, Ottawa, Ontario, Canada. [online] URL: http://www12.statcan. gc.ca/census-recensement/2011/dp-pd/prof/details/page.cfm?Lang= E\&Geo1 $=$ CSD $\&$ Code $1=4803011 \&$ Geo $2=$ PR \&Code $2=01 \&$ Data $=$ Count\&SearchText $=$ Pincher $\% 20$ Creek $\&$ SearchType $=$

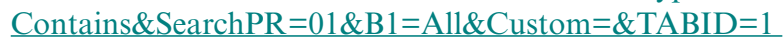

Statistics Canada. 2016. Census Profile, 2016 Census: Pincher Creek No. 9, Municipal district [Census subdivision], Alberta and Division No. 3, Census division [Census division], Alberta. Statistics Canada, Ottawa, Ontario, Canada. [online] URL: http://www12.statcan.gc.ca/census-recensement/2016/dp-pd/prof/ details/page.cfm?Lang $=\mathrm{E} \& \mathrm{Geo} 1=\mathrm{CSD} \& \mathrm{Code} 1=4803011 \& \mathrm{Geo} 2=$ $\underline{\text { CD\&Code } 2=4803 \& D a t a}=$ Count $\&$ SearchText $=$ pincher $\%$ 20 creek $\&$ SearchType $=$ Begins $\&$ SearchPR $=01 \& B 1=$ All $\&$ TABID $=1$

Stone, S. A., S. W. Breck, J. Timberlake, P. M. Haswell, F. Najera, B. S. Bean, and D. J. Thornhill. 2017. Adaptive use of nonlethal strategies for minimizing wolf-sheep conflict in Idaho. Journal of Mammalogy 98:33-44. http://dx.doi.org/10.1093/jmammal/gyw188

Swenson, J. E. 1999. Does hunting affect the behavior of brown bears in Eurasia? Ursus 11:157-162.

Thapa, S. 2010. Effectiveness of crop protection methods against wildlife damage: a case study of two villages at Bardia National Park, Nepal. Crop Protection 29:1297-1304. http://dx.doi. org/10.1016/j.cropro.2010.06.015

Treves, A. 2009. Hunting for large carnivore conservation. Journal of Applied Ecology 46:1350-1356. http://dx.doi.org/10.1111/ j.1365-2664.2009.01729.x

Treves, A., and L. Naughton-Treves. 1999. Risk and opportunity for humans coexisting with large carnivores. Journal of Human Evolution 36:275-282. http://dx.doi.org/10.1006/jhev.1998.0268

Van Bommel, L., and C. N. Johnson. 2012. Good dog! Using livestock guardian dogs to protect livestock from predators in Australia's extensive grazing systems. Wildlife Research 39:220-229. http://dx.doi.org/10.1071/WR11135 
Voyles, Z., A. Treves, and D. MacFarland. 2015. Spatiotemporal effects of nuisance black bear management actions in Wisconsin. Ursus 26:11-20. http://dx.doi.org/10.2192/ursus-d-14-00038.1

Vucetich, J. A., J. T. Bruskotter, and M. P. Nelson. 2015. Evaluative whether nature's intrinsic value is an axiom of or anathema to conservation. Conservation Biology 29:321-332. http://dx.doi. org/10.1111/cobi.12464

Wilson, S. M., M. J. Madel, D. J. Mattson, J. M. Graham, J. A. Burchfield, and J. M. Belsky. 2005. Natural landscape features, human-related attractants, and conflict hotspots: a spatial analysis of human-grizzly bear conflicts. Ursus 16:117-129. http:// dx.doi.org/10.2192/1537-6176(2005)016[0117:NLFHAA]2.0.CO;2

Wilson, S. M., M. J. Madel, D. J. Mattson, J. M. Graham, and T. Merrill. 2006. Landscape conditions predisposing grizzly bears to conflicts on private agricultural lands in the western USA. Biological Conservation 130:47-59. http://dx.doi.org/10.1016/j. biocon.2005.12.001

Wilson, S. M., G. A. Neudecker, and J. J. Jonkel. 2014. Humangrizzly bear coexistence in the Blackfoot River Watershed, Montana: getting ahead of the conflict curve. Pages 177-214 in S. G. Clark and M. B. Rutherford, editors. Large carnivore conservation: integrating science and policy in the North American West. University of Chicago Press, Chicago, Illinois, USA. http:// dx.doi.org/10.7208/chicago/9780226107547.003.0006

Woodroffe, R., and J. R. Ginsberg. 1998. Edge effects and the extinction of populations inside protected areas. Science 280:2126-2128. http://dx.doi.org/10.1126/science.280.5372.2126

Young, K. R. 1997. Wildlife conservation in the cultural landscapes of the central Andes. Landscape and Urban Planning 38:137-147. http://dx.doi.org/10.1016/S0169-2046(97)00029-7 